\title{
$v a c A$ genotypes in oral cavity and Helicobacter pylori seropositivity among adults without dyspepsia
}

\author{
Gloria Fernández-Tilapa ${ }^{1}$, Jazmín Axinecuilteco-Hilera ${ }^{2}$, Silvia Giono-Cerezo ${ }^{3}$, Dinorah-Nashely Martínez- \\ Carrillo ${ }^{1}$, Berenice Illades-Aguiar ${ }^{4}$, Adolfo Román-Román ${ }^{1}$
}

\footnotetext{
${ }^{1}$ Research Professor; Laboratorio de Investigación Clínica, Unidad Académica de Ciencias Químico Biológicas, Universidad Autónoma de Guerrero, Chilpancingo, Guerrero, México

${ }^{2}$ Master's student in Biomedical Sciences. Unidad Académica de Ciencias Químico Biológicas, Universidad Autónoma de Guerrero, Chilpancingo, Guerrero, México

${ }^{3}$ Research Professor; Laboratorio de Bacteriología Médica, Departamento de Microbiología, Escuela Nacional de Ciencias Biológicas, Instituto Politécnico Nacional, México, D.F.

${ }^{4}$ Research Professor; Laboratorio de Biomedicina Molecular, Unidad Académica de Ciencias Químico Biológicas, Universidad Autónoma de Guerrero. Chilpancingo, Guerrero, México
}

Correspondence:

Laboratorio de Investigación Clínica, Planta baja, edificio " $C$ ", Unidad Académica de Ciencias Químico Biológicas, Universidad Autónoma de Guerrero.

Av. Lázaro Cárdenas $S / N$, Colonia Haciendita, Ciudad Universitaria. Chilpancingo, Guerrero. CP 39090 gferti@hotmail.com

Received: $14 / 03 / 2010$ Accepted: 04/06/2010
Fernández-Tilapa G, Axinecuilteco-Hilera J, Giono-Cerezo S, MartínezCarrillo DN, Illades-Aguiar B, Román-Román A. vacA genotypes in oral cavity and Helicobacter pylori seropositivity among adults without dyspepsia. Med Oral Patol Oral Cir Bucal. 2011 Mar 1;16 (2):e175-80. http://www.medicinaoral.com/medoralfree01/v16i2/medoralv16i2p175.pdf

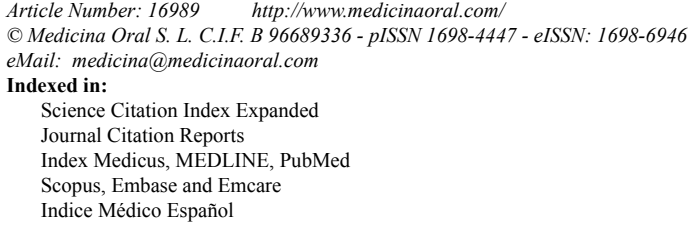

\begin{abstract}
Objective: The aims of this research were to determine the prevalence of Helicobacter pylori and its vacA genotypes in oral cavity in persons without dyspepsia and to establish the association between the presence of $\mathrm{H}$. pylori in oral cavity and oral hygiene. The seroprevalence of anti-H. pylori antibodies and its associated factors were analyzed too. Study design: For the study, 200 adults without dyspepsia symptoms were selected. Dental plaque and saliva samples from each subject were obtained. H. pylori detection in oral samples was carried out by polymerase chain reaction (PCR) and for $v a c A$ genotyping a semi-nested and nested PCR was used. The enzyme-linked immunosorbent assay (ELISA) was used to detect anti-H. pylori IgG and IgM. The data were analyzed with Chi square and Fisher exact test and the statistical significance was set to 0.05 .

Results: Of 200 subjects tested, $124(62 \%)$ were seropositive. H. pylori was detected in the oral cavity of 34 subjects $(17 \%)$ and vacA allelotypes were typified in 12 of those samples. The s1 allele was detected in $8(66.7 \%)$ samples and in one of them $\mathrm{m} 1$ and $\mathrm{m} 2$ alleles were found. In four subjects $v a c A \mathrm{~m} 1$ subtypes were found and in two of those both $\mathrm{m} 1$ and $\mathrm{m} 2$ alleles were detected. The prevalence of $H$. pylori in oral cavity was higher (18.5\%) among seropositive subjects compared with seronegative persons. No association was found between the presence of $H$. pylori and oral hygiene habits.

Conclusions: The presence of $H$. pylori in oral cavity is more frequent in seropositive subjects without dyspepsia symptoms and could represent the source of gastric infection and bacterial transmission. The data suggest that more than one H. pylori strain may exist in the mouth of asymptomatic persons.
\end{abstract}

Key words: Helicobacter pylori, antibodies, dental plaque, genotypes. 


\section{Introduction}

Helicobacter pylori colonizes the human stomach and its persistence is associated with the development of chronic gastritis, peptic ulcer and gastric cancer. This bacterium is distributed worldwide and its prevalence greatly varies with geographic areas and population age (1). The transmission mechanism is not well established but infected saliva or food contamination seems to be most probable (2). The H. pylori DNA has been detected in saliva and dental plaque from patients with gastroduodenal pathology (3-7). This fact strengthens the hypothesis that the oral cavity is a reservoir for $H$. pylori, it could be the source for gastric infection and re-infection post therapy as well as person-to-person transmission (3). Nevertheless, the role H. pylori plays in the oral cavity is controversial since the detection rate of the bacterium in the mouth is $0 \%$ to $100 \%(3-8)$. Gastroesophagic reflux, deficient oral hygiene and frequent vomiting are conditions that may facilitate oral colonization and also the environment and life-style could be decisive for $H$. pylori infection (4).

Only a few of the persons infected develop gastric disease and this event is related to the expression of virulence genes vacA and $\operatorname{cag} A$. vacA gene is polymorphic and the levels of production of the cytotoxin were closely associated with $v a c A$ genotype. $H$. pylori strains with $v a c A s 1 / m 1$ genotype produce high cytotoxin levels, the $\mathrm{s} 1 / \mathrm{m} 2$ strains moderate levels and $\mathrm{s} 2 / \mathrm{m} 2$ strains produce minimal or no concentration of toxin. The vacA $\mathrm{s} 1$ and $\mathrm{m} 1$ allelotypes are associated with epithelial damage, peptic ulcer and gastric cancer (9). The $H$. pylori vacA gene is one of the most studied genes related to the pathogenesis in the gastric mucosa but the published data on the presence of this gene in the oral cavity are scarce $(10,11)$. It is not known if the bacterial allelotypes that colonize the mouth are the most frequently found in the stomach of patients with gastritis, ulcer or gastric cancer. Typifying the oral H. pylori will give useful data about the role that oral cavity plays in bacterial transmission.

The aim of this study was to assess the prevalence of H. pylori vacA genotypes in the oral cavity of persons without dyspepsia and to investigate the relationship between this infection and the oral hygiene habits. Prevalence of IgM and IgG anti- $H$. pylori serum antibodies and their relationship with risk factors for the infection acquisition or gastritis onset were also investigated. Another additional purpose was to examine the correlation between the presence of these bacteria in the oral cavity and $H$. pylori seropositivity.

\section{Materials and Methods}

-Population selection. A total of 200 adults (over 18 years of age) without dyspepsia symptoms participated in this study. Those with a history of $H$. pylori infection or any gastroduodenal disease associated with these bacteria were excluded. None of the subjects had received nonsteroidal anti-inflammatory drugs, antacids or any antibiotics within two months before sampling. The participants signed a consent form and answered a questionnaire about personal data, oral hygiene habits and stress (12). The project was approved by the Bioethics Committee of the Autonomous University of Guerrero.

-Samples. Sterile Gracey curettes (Hu-friedy, USA) were used to collect supragingival plaque. Saliva samples $(2-3 \mathrm{~mL})$ and dental plaque were placed in the same sterile polypropylene flasks containing digestion buffer [100 mM NaCL, $10 \mathrm{mM}$ Tris $\mathrm{HCl}(\mathrm{pH} 8.0), 20 \mathrm{mM}$ EDTA (pH 8.0) and $0.5 \%$ SDS] and were kept at $-20{ }^{\circ} \mathrm{C}$ until DNA extraction. Additionally $3 \mathrm{~mL}$ of blood were also collected by venous puncture and the serum was kept at $-20^{\circ} \mathrm{C}$ until the IgM and IgG detection.

-Anti-H. pylori antibodies test. The H. pylori infectious status was determined serologically using a commercially available enzyme-linked immunosorbent assay (ELISA) with a sensitivity and specificity of $96 \%$ and 97\%, respectively (H. pylori IgG e IgM EIA assay, Internacional Immuno-Diagnostic, Foster, CA, USA). A person was considered H. pylori-positive when one or both antibodies were detected.

$-H$. pylori detection. All samples from saliva-dental plaque were added with proteinase $\mathrm{K}$ solution $(20 \mathrm{mg} /$ $\mathrm{mL}$ ) and incubated at $65^{\circ} \mathrm{C}$ until the sample material was dissolved completely. Total genomic DNA was obtained from saliva-dental plaque using the phenol-chloroform-iso-amylic alcohol method (7). H. pylori DNA was detected with the primers HP16-219 5'-GCTAAGAGATCAGCCTATGTCC-3' and HPGR16SR 5'CAATCAGCGTCAGTAATGTTC-3'that amplify a region of $522 \mathrm{pb}$ of the rRNA $16 \mathrm{~S}$ gene. The PCR reaction mix consisted of $450 \mathrm{ng}$ of total DNA, $2.5 \mathrm{mM} \mathrm{MgCl}{ }_{2}$, 0.2 mM dNTP's (Invitrogen, Carlsbad, CA, USA), 10 pmol of each primer and $1 \mathrm{U}$ of Platinum ${ }^{\circledR}$ Taq DNA Polymerase (Invitrogen, Carlsbad, CA, USA). After an initial denaturation step of $94{ }^{\circ} \mathrm{C}$ for 5 minutes, there were 40 cycles with denaturation at $94{ }^{\circ} \mathrm{C}$ for 30 seconds, annealing at $55^{\circ} \mathrm{C}$ for 30 seconds, extension at $72{ }^{\circ} \mathrm{C}$ for 1 minutes and the last extension at $72{ }^{\circ} \mathrm{C}$ for 7 minutes.

The PCR-amplified products were analyzed by electrophoresis on $1.5 \%$ agarose gels. The gels were stained with ethidium bromide and examined under UV light.

$-H$. pylori vacA genotyping. For the $H$. pylori-positive samples a semi-nested and nested PCR was used for genotyping the $v a c A$ gene with the primers reported by 
Koehler et al. (13). The PCR reaction mix consisted of $3 \mu \mathrm{g}$ of total DNA, $1 \mathrm{mM}$ of $\mathrm{MgCl}_{2}, 0.15 \mathrm{mM}$ of dNTP's, 10 pmol of each primer and $1 \mathrm{U}$ of Platinum ${ }^{\circledR}$ Taq DNA polymerase. The first amplification included an initial denaturation step at $95{ }^{\circ} \mathrm{C}$ for 3 minutes, then followed by 23 cycles at $95{ }^{\circ} \mathrm{C}$ for 40 seconds; $58^{\circ} \mathrm{C}$ for $40 \mathrm{sec}-$ onds, $72{ }^{\circ} \mathrm{C}$ for 45 seconds and one cycle at $72{ }^{\circ} \mathrm{C}$ for 3 minutes. For the second PCR amplification, $1 \mu \mathrm{L}$ DNA template from the first PCR and $10 \mathrm{pmol}$ of each primer were used and PCR was performed according to the PCR protocol described above, 34 cycles of amplification were performed. The PCR products were resolved by electrophoresis in 3\% agarose gels. The three vacA primers generate 120 and $150 \mathrm{pb}$ which corresponded to $\mathrm{s} 1$ and $\mathrm{s} 2$ alleles, respectively. For the $\mathrm{m} 2$ allele a band of $102 \mathrm{pb}$ could be detected in agarose gel. The PCR product of vacA $\mathrm{ml}$ was subjected to electrophoresis in $1.5 \%$ agarose gel and the samples were scored as positive when a band of $301 \mathrm{pb}$ was observed. DNA of the ATCC43504 strain was used as a positive control for H. pylori and for the vacA s1/m1 genotype and it was included in each batch of PCR assays, as a negative control the template DNA was substituted by sterile deionized water. For the $\mathrm{m} 2$ region, as a positive control was used DNA from gastric biopsy which contained that allelotype. All PCR reactions were run in a thermocycler Mastercycler Ep gradient (Eppendorf, Germany).

-Statistical analysis. The STATA v. 9.0 program was used for the statistical analysis. Absolute and relative frequencies of the qualitative variables were obtained. The kappa index was used to calculate the concordance of the presence of anti-H pylori antibodies with the presence of bacterial DNA in the oral samples. The Chi square or Fisher's test was used to compare ratios of qualitative variables and to establish differences between groups. A p $<0.05$ was considered significant.

\section{Results}

A total of 200 adults without dyspepsia participated in this study. Among these, 136 (68\%) were females and 64 $(32 \%)$ were males. The median age for the study group was 29.5 years of age. The academic status varied from analphabetic to post graduate studies and the occupations were diverse.

Anti-H. pylori antibodies were found in 124 (62\%) persons. Most of the seropositive subjects ate unclean street food, drank carbonated soft drinks (sodas), alcohol, coffee, and smoked. There were no significant differences with the presence of anti-H. pylori antibodies and risk factors that favour infection or gastric pathology (Table 1).

Two hundred samples from oral cavity (saliva and dental plaque from the same patient mixed together) were studied.

H. pylori was detected in $34(17 \%)$ oral samples from
$23(68 \%)$ women and from $11(32 \%)$ men. Of the persons that were $H$. pylori-positive, $20(58.8 \%)$ were in the age group 20-39 years old. Even though there was no significant correlation between the presence of $\mathrm{H}$. pylori in oral cavity and oral hygiene habits $23(67.6 \%)$ of the 34 positive persons brushed their teeth once or twice a day and used neither mouthwash nor dental floss. H. pylori was detected in the mouth of $23(18.5 \%)$ of the 124 seropositive persons and in 11 (14.5\%) who did not present antibodies to the bacterium. There is no agreement between the anti-H. pylori antibodies and the presence of bacteria in the mouth. The kappa value was 0.033 .

The vacA allelic variants were subtyping in 12 (35.3\%) of the $34 \mathrm{H}$. pylori-positive subjects in oral samples. The vacA sl allele was found in $8(66.7 \%)$ of 12 oral samples and one of them contained mixed vacA alleletypes $\mathrm{s} 1 /$ $\mathrm{m} 1 \mathrm{~m} 2$. By other hand a mix of $v a c A \mathrm{~m} 1$ and $\mathrm{m} 2$ alleles was found in $2(16.7 \%)$ samples (Table 2). Most of the oral samples did not yield a detectable PCR product for the vacA $\mathrm{s}$ or $\mathrm{m}$ regions.

\section{Discussion}

In this research we found that prevalence of anti- $H$. pylori antibodies was $62 \%$, which is close to the $66 \%$ national seroprevalence in the general population (14). The difference might be due to several factors: genetic, geographic and socio-economic proper to each population plus to differences in the bacterial strains that originated the antigens used in antibody detection (15). More than $70 \%$ of the seropositive subjects used to drink alcohol, sodas and coffee, so this group might have a greater probability to develop gastric pathology. There was not a relationship between the presence of $H$. pylori antibodies and age, sex, over-crowding, smoking or alcohol consumption. Our results agree with those reported by other authors $(16,17)$.

H. pylori is believed to be transmitted from person to person through the oral cavity. The hypothesis that the mouth is a reservoir for $H$. pylori and a potential source of gastric infection is strengthened by several reports of $H$. pylori DNA in the saliva and dental plaque (3-8).

Among the techniques to detect $\mathrm{H}$. pylori in the oral cavity, Polymerase Chain Reaction (PCR) has demonstrated to be specific and sensible, that is why it is considered the method of choice to detect DNA from $H$. pylori in the oral cavity $(2,4,10)$. Studies that employed culture methods failed to detect the bacterium in oral samples. One reason may be the presence of viable but non-culturable coccoid $H$. pylori organisms $(2-5,10,11)$.

In order to increase the number of bacteria in the sample and the probability of finding H.pylori DNA we mixed together the oral samples (dental plaque-saliva) from de same patient before preparation of genomic DNA for 
Table 1. Socio-demographic characteristics and H. pylori status of subjects without dyspepsia

\begin{tabular}{|c|c|c|c|}
\hline & $\begin{array}{c}\text { Seropositive } \\
(\mathrm{n}=124)\end{array}$ & $\begin{array}{c}\text { Seronegative } \\
(\mathrm{n}=76)\end{array}$ & p value \\
\hline & $\mathrm{n}(\%)$ & $\mathrm{n}(\%)$ & \\
\hline \multicolumn{4}{|l|}{ Age } \\
\hline 20 years old & $8(6.5)$ & $6(7.9)$ & \multirow{4}{*}{$0.626^{*}$} \\
\hline 20-39 years old & $73(58.8)$ & $49(64.5)$ & \\
\hline 40-59 years old & $35(28.2)$ & $19(25)$ & \\
\hline$>60$ years old & $8(6.5)$ & $2(2.6)$ & \\
\hline \multicolumn{4}{|l|}{$\operatorname{Sex}$} \\
\hline Female & $89(71.8)$ & $47(61.8)$ & \multirow[t]{2}{*}{$0.144^{\ddagger}$} \\
\hline Male & $35(28.2)$ & $29(38.2)$ & \\
\hline \multicolumn{4}{|l|}{ Over-crowding } \\
\hline No & $85(68.5)$ & $50(65.8)$ & \multirow{2}{*}{$0.686^{\ddagger}$} \\
\hline Yes & $39(31.5)$ & $26(34.2)$ & \\
\hline \multicolumn{4}{|l|}{ Street-food eating } \\
\hline No & $35(28.2)$ & $19(25)$ & \multirow{2}{*}{$0.618^{¥}$} \\
\hline Yes & $89(71.8)$ & $57(75)$ & \\
\hline \multicolumn{4}{|l|}{ Vegetable desinfection } \\
\hline No & $26(21)$ & $24(31.6)$ & \multirow{2}{*}{$0.093^{¥}$} \\
\hline Yes & $98(79)$ & $52(68.4)$ & \\
\hline \multicolumn{4}{|l|}{ Smoking } \\
\hline No & $62(50)$ & $34(44.7)$ & \multirow[t]{2}{*}{$0.470^{\ddagger}$} \\
\hline Smoker and ex-smoker & $62(50)$ & $42(55.3)$ & \\
\hline \multicolumn{4}{|l|}{ Alcohol drinking } \\
\hline No & $22(17.7)$ & $11(14.5)$ & \multirow[t]{2}{*}{$0.546^{¥}$} \\
\hline Drinker or ex-drinker & $102(82.3)$ & $65(85.5)$ & \\
\hline \multicolumn{4}{|l|}{ Sodas drinking } \\
\hline No & $14(11.3)$ & $7(9.2)$ & \multirow[t]{2}{*}{$0.641^{¥}$} \\
\hline Yes & $110(88.7)$ & $69(90.8)$ & \\
\hline \multicolumn{4}{|l|}{ Coffee drinking } \\
\hline No & $37(29.8)$ & $25(32.9)$ & \multirow[t]{2}{*}{$0.650^{¥}$} \\
\hline Yes & $87(70.2)$ & $51(67.1)$ & \\
\hline \multicolumn{4}{|l|}{ Stress } \\
\hline No & $57(46)$ & $36(47.4)$ & \multirow[t]{2}{*}{$0.847^{¥}$} \\
\hline Yes & $67(54)$ & $40(52.6)$ & \\
\hline
\end{tabular}

Table 2. H. pylori vacA alleles in oral samples from subjects without dyspepsia symptoms.

\begin{tabular}{ccc}
\hline $\boldsymbol{v a c} \boldsymbol{A}$ alleles & $\mathbf{n}$ & $\mathbf{( \% )}$ \\
\hline $\mathrm{s} 2$ & 1 & 8.3 \\
$\mathrm{~s} 1$ & 7 & 58.5 \\
$\mathrm{~m} 1$ & 1 & 8.3 \\
$\mathrm{~m} 1 \mathrm{y} \mathrm{m} 2$ & 2 & 16.6 \\
$\mathrm{~s} 1, \mathrm{~m} 1 \mathrm{y} \mathrm{m} 2$ & 1 & 8.3 \\
Total & 12 & 100 \\
\hline
\end{tabular}


PCR. A preferred intra-oral habitat has not been identified for $H$. pylori and the detection rate in dental plaque and saliva has been very variable $(2-5,10,11)$.

In this study we only used the PCR test to detect the DNA of H. pylori and the detection rate in the oral cavity was low $(17 \%)$ but the frequency agrees or surpasses the reports of other authors in asymptomatic populations $(4,18)$. H. pylori detection rate in the oral cavity varies from zero (8-10) to high infection frequencies (3, 5-7,18). These discrepancies could be attributed to differences in the socio-economic conditions, geographic areas, hygiene habits and food ingestion but also to the way the samples are collected and the oligonucleotides and the protocols used, all of which might modify the specificity and sensitivity of the detection methods (2). The highest proportion $(58.8 \%)$ of the oral H. pylori positive subjects was in the age group 20-39 years old and this frequency was higher than the one reported by Berroteran et al. (3). This finding might be due to kissing and other relationships in this age group that favours the bacterial transmission. Female predominated among subjects with positive samples for $H$. pylori in oral cavity $(68 \%)$ but the difference between sexes was not statistically significant. Similar results have been reported by other authors (4). In our study it is probable that the differences are due to a higher female participation. The reported oral colonization prevalence varies even though there were no data to associate the infection with gender $(3,4,6)$.

There was not a direct relation between $H$. pylori presence and teeth brushing frequency or with dental floss but a relationship might be found in the way the brushing is done. The type of mouthwash and the frequency that was used was not analysed in this research but has to be considered in later studies. We do not reject the possibility that these results might be biased by untrue data given in the questionnaire concerning oral hygiene.

Berroteran et al. concluded that the dental plaque can be an important reservoir for H. pylori (3). In our study, $88.2 \%$ of the oral $H$. pylori positive individuals mentioned that they do not floss their teeth so maybe the dental plaque accumulation might be a bacterial reservoir.

H. pylori was detected in the oral cavity in $18.5 \%$ of the seropositive subjects and in $14.5 \%$ of those who did not show anti-H. pylori antibodies. It is possible that this result is related to the reports that propose that $H$. pylori can reach the stomach after a previous residence in the oral cavity or that a low number of bacteria can persist in the mouth for long periods of time without colonizing the stomach $(5,7)$. The disagreement between anti-H. pylori antibody presence and bacterial DNA in oral samples shows that the test results are independent and therefore both assays are complementary. We recommend the H. pylori searching in the oral cavity as an auxiliary tool for the diagnosis of infection by this bacterium.

In $35.3 \%$ of $H$. pylori positive subjects allelic variants of $v a c A$ were found. The s1 vacA allele was detected in 8 samples but only in one of them the $\mathrm{m} 1$ and $\mathrm{m} 2$ allele combination was found. The $\mathrm{m} 1$ and $\mathrm{m} 2$ alleles were found in 2 subjects. Our results suggest that more than one $H$. pylori strain may exist in the mouth of the same person. It is documented that humans might be infected with 2 or more $H$. pylori strains and that the oral environment, which is first colonized, might help to generate the different $H$. pylori strains that infect the stomach (11). As far as we know this is the first study of genotyping $v a c A$ in oral samples from subjects without dyspepsia symptoms. Interestingly our results show that the H. pylori strains with the vacA sl alleles are predominant in the mouth and coincide with most of the ones found in Mexican patients with severe gastric pathology $(19,20)$.

We conclude that the prevalence of anti- $H$. pylori antibodies shows that this bacterial infection is very frequent in the Mexican population that does not have dyspepsia symptoms and also that the persistent infection with other risk factors could bring about gastritis. The presence of the bacterium in the oral cavity of asymptomatic persons might be the source for gastric infection. The study of oral samples and serologic assays are complementary for the diagnosis of infection in asymptomatic persons. The vacA allelic variants in the mouth of this study group are the same as those detected by other authors in gastric biopsies of Mexican patients with chronic gastritis, gastric ulcers and gastric cancer $(19,20)$. On the other hand, the mouth can be colonized by more than one strain of $H$. pylori.

\section{References}

References with links to Crossref - DOI

1. Suerbaum S, Michetti P. Helicobacter pylori infection. N Engl J Med. $2002 ; 347: 1175-86$

2. Song Q, Lange T, Spahr A, Adler G, Bode G. Characteristic distribution pattern of Helicobacter pylori in dental plaque and saliva detected with nested PCR. J Med Microbiol. 2000;49:349-53.

3. Berroteran A, Perrone M, Correnti M, Cavazza ME, Tombazzi C, Goncalvez R, et al. Detection of Helicobacter pylori DNA in the oral cavity and gastroduodenal system of a Venezuelan population. J Med Microbiol. 2002;51:764-70.

4. Medina ML, Medina MG, Martín GT, Picón SO, Bancalari A, Merino LA. Molecular detection of Helicobacter pylori in oral samples from patients suffering digestive pathologies. Med Oral Patol Oral Cir Bucal. 2010;15:e38-42.

5. Tiwari SK, Khan AA, Ahmed KS, Ahmed I, Kauser F, Hussain MA, et al. Rapid diagnosis of Helicobacter pylori infection in dyspeptic patients using salivary secretion: a non-invasive approach. Singapore Med J. 2005;46:224-8.

6. Ahmed KS, Khan AA, Ahmed I, Tiwari SK, Habeeb MA, Ali SM, et al. Prevalence study to elucidate the transmission pathways of Helicobacter pylori at oral and gastroduodenal sites of a South Indian population. Singapore Med J. 2006;47:291-6.

7. Li C, Musich PR, Ha T, Ferguson DA Jr, Patel NR, Chi DS, et al. High prevalence of Helicobacter pylori in saliva demonstrated by a novel PCR assay. J Clin Pathol. 1995;48:662-6. 
8. Olivier BJ, Bond RP, van Zyl WB, Delport M, Slavik T, Ziady $\mathrm{C}$, et al. Absence of Helicobacter pylori within the oral cavities of members of a healthy South African community. J Clin Microbiol. 2006;44:635-6.

9. Atherton JC, Cao P, Peek RM Jr, Tummuru MK, Blaser MJ, Cover TL. Mosaicism in vacuolating cytotoxin alleles of Helicobacter pylori. Association of specific vacA types with cytotoxin production and peptic ulceration. J Biol Chem. 1995;270:17771-7.

10. Silva Rossi-Aguiar VP, Navarro-Rodriguez T, Mattar R, Siqueira de Melo Peres MP, Correa Barbuti R, Silva FM, et al. Oral cavity is not a reservoir for Helicobacter pylori in infected patients with functional dyspepsia. Oral Microbiol Immunol. 2009;24:255-9.

11. Wang J, Chi DS, Laffan JJ, Li C, Ferguson DA Jr, Litchfield P, et al. Comparison of cytotoxin genotypes of Helicobacter pylori in stomach and saliva. Dig Dis Sci. 2002;47:1850-6.

12. Zigmond AS, Snaith RP. The hospital anxiety and depression scale. Acta Psychiatr Scand. 1983;67:361-70.

13. Koehler CI, Mues MB, Dienes HP, Kriegsmann J, Schirmacher $\mathrm{P}$, Odenthal $\mathrm{M}$. Helicobacter pylori genotyping in gastric adenocarcinoma and MALT lymphoma by multiplex PCR analyses of paraffin wax embedded tissues. Mol Pathol. 2003;56:36-42.

14. Torres J, Leal-Herrera Y, Perez-Perez G, Gomez A, CamorlingaPonce M, Cedillo-Rivera R, et al. A community-based seroepidemiologic study of Helicobacter pylori infection in Mexico. J Infect Dis. 1998;178:1089-94.

15. Hoang TT, Wheeldon TU, Bengtsson C, Phung DC, Sörberg M, Granström M. Enzyme-linked immunosorbent assay for Helicobacter pylori needs adjustment for the population investigated. J Clin Microbiol. 2004;42:627-30.

16. Rodrigues MN, Queiroz DM, Rodrigues RT, Rocha AM, Braga Neto MB, Braga LL. Helicobacter pylori infection in adults from a poor urban community in northeastern Brazil: demographic, lifestyle and environmental factors. Braz J Infect Dis. 2005;9:405-10.

17. Martín-de-Argila C, Boixeda D, Cantón R, Mir N, de Rafael L, Gisbert J, et al. Helicobacter pylori infection in a healthy population in Spain. Eur J Gastroenterol Hepatol. 1996;8:1165-8.

18. Souto R, Colombo AP. Detection of Helicobacter pylori by polymerase chain reaction in the subgingival biofilm and saliva of non-dyspeptic periodontal patients. J Periodontol. 2008;79:97-103.

19. Morales-Espinosa R, Castillo-Rojas G, Gonzalez-Valencia G, Ponce de León S, Cravioto A, Atherton JC, et al. Colonization of Mexican patients by multiple Helicobacter pylori strains with different vacA and cagA genotypes. J Clin Microbiol. 1999;37:3001-4.

20. Garza-Gonzalez E, Bosques-Padilla FJ, Tijerina-Menchaca R, Perez-Perez GI. Characterisation of Helicobacter pylori isolates from the north-eastern region of Mexico. Clin Microbiol Infect. 2004; $10: 41-5$. 